International Research Journal of Management, IT \& Social Sciences
Available online at https://sloap.org/journals/index.php/irjmis/
Vol. 8 No. 3, May 2021, pages: 274-285
ISSN: 2395-7492
https://doi.org/10.21744/irjmis.v8n3.1667

\title{
The Sustainable Business Strategy during the New Normal Era: Lesson for Indonesian Academic
}

\author{
Abdul Samad Arief ${ }^{\text {a }}$ \\ Mulyadi $^{\text {b }}$ \\ Fahrina Yustiasari Liriwati ${ }^{c}$
}

\section{Article history:}

Submitted: 18 March 2021

Revised: 9 April 2021

Accepted: 7 May 2021

\section{Keywords:}

academic lesson;

business strategy;

business sustainability;

new normal era;

\begin{abstract}
This study examined ten sustainable business strategies that more experts have advised use running a business in the new normal era. Many findings went publication on a variety of profitable business strategies. However, very little has discussed in a balanced proportion between gaining profitable business and design with high sustainable value. Conditionally, running a business requires a variety of strategic approaches that are sustainable following the policy of the COVID-19 protocol. Understanding which strategies align with the above expectations, we have conducted a series of online literature studies using qualitative methods based on a phenomenological approach. Then, they were analyzed using the conceptual framework of higher education research skills. Through this process, the authors ensured that these findings are valid and reliable. Finally, we summarized ten relevant, sustainable business strategies that are relevant to be applied in the new normal business era in Indonesia. They include continuity strategy, business to business, opportunity strategy, rethinking, lesson learned strategies, working from home, affected policies, new thinking patterns, flexibility strategies, and understanding of new processes. Therefore, these findings will provide profound insight for business people and academicians to work on business practices' sustainability to facing the pandemic disruption.
\end{abstract}

International research journal of management, IT and social sciences (C) 2021. This is an open access article under the CC BY-NC-ND license (https://creativecommons.org/licenses/by-nc-nd/4.0/).

\section{Corresponding author:}

Mulyadi,

STAI Auliaurrasyidin Tembilahan Riau, Indonesia.

Email address: mulyadi@stai-tbh.ac.id

\footnotetext{
aniversitas Fajar, Indonesia. Email: abdulsamad@unifa.ac.id

b STAI Auliaurrasyidin Tembilahan Riau, Indonesia.

STAI Auliaurrasyidin Tembilahan Riau, Indonesia.Email: fahrina.yustiasari@stai-tbh.ac.id 


\section{Introduction}

Since mid-March 2020, the Indonesian government officially issued a partial physical locking policy. Such social distance policy enforced nationally, and the public responded to help break the chain of the spread of the Corona 2019, which more people believed it to spread in public places such as educational institutions, markets, houses of worship, and other crowded places. This national decision is part of joining the international community's collective response to the dangers of a coronavirus, the one similar to SARS-CoV that has spread to many countries after the first time the world health agency (WHO) confirmed the Coronavirus originated from the city of Wuhan, China at the end of November 2019. The Coronavirus 2019 is a type of virus that attacks the respiratory system and has infected more than 15 million people worldwide from more than 200 confirmed countries (Sirkeci and Yucesahin, 2020; Sigler et al., 2020; Sun et al., 2020; Cohen, 2020; Geissdoerfer et al., 2018). Scientifically, the COVID-19 has proven that this pandemic is not only a matter of health that has strict regulations and restrictive policies, but that has also led to the consequences of other difficulties such as breaking the economic chain, job loss, and other risks in economic activities both the government and public business in general, global, national and regional. Therefore, the COVID-19 solution needs a collective approach to lower human life's impact on entering the new normal era.

Many studies continuously report that the government closure and stopping of these public places have not only reduced the number of cases of the Covid-19 but also has affected various obstacles for many economic, educational, and religious activities which are now entering the sixth month of experiencing the difficulties arise in various community business as well as the government activities (Subroto, 2020; Bocken et al., 2014). According to Subroto, the impact of Covid-19 on the community's lives that needs joint attention because of this impact is becoming a matter of human health and the economic losses in various national and regional sectors. Therefore, this typical trend requires collective support and thought so that these conditions are solved immediately. Referring to much literature, the production sector and human welfare have become the most detrimental targets, so this requires practical solutions to revive the economy, especially through various strategies of people's business activities which have now reached the lowest growth rates since the last ten years (Crick \& Crick, 2020); (Hofacker, 2020; Joyce \& Paquin, 2016). Besides, when the question of how the Coronavirus has impacted the country's economy, even though this outbreak was first just a foreign issue, one can understand how business conditions and the implications for all economic activities will generate. The most visible impacts are the trend, such as education and business closure, people only work from home, decreased purchasing, cessation of economic mobility between countries, and almost all potential food business activities, health care, tourism, and other restrictions.

The current uncertainty of the various conditions and complexities in Indonesia affected by the Covid-19 pandemic, this impact should not be seen as an obstacle to contribute to a solution. In a productive academic perspective, this condition must be an opportunity for innovation in the form of teaching and other strategic studies towards recovery efforts by concentrating on solutions to get out of trouble periodically and specifically, such as health and public financial impact (Prideaux et al., 2009; Naumov et al., 2020; Cai et al., 2020; Caldera et al., 2019). They suggested that every country affected, its citizens should take lessons to take steps to sustainably and synergistically prepared for national economic recovery through various activities such as capacity building through academics and other studies to strengthen human resources for innovative and strategic change. For example, efforts to respond to economic conditions in pandemic countries that have implications for gross domestic product, for instance, due to pandemics, Indonesia's economic growth has dropped dramatically to $2.98 \%$ from 2020 Caraka et al. (2020), (Toharudin et al., 2020, Novitasari et al., (2020), finding suggested that the impact of pandemic Covid-19 after partial restriction on public activities has resulted in national economic crisis. Then all components of the nation must be involved synergistically and collaborative for joint goals, the contribution of national economic development specifically through study and teaching.

In this case, the academic community's involvement in the government's efforts to accelerate economic recovery is possible because authentic evidence from various economists about the sudden impact of semi-limited policies since the emergence of the pandemic is very positive and strategic. The reason is with the active involvement of multiple institutions of higher education institutions supported by innovative studies; they may prove to be able to provide solutions so that in the future, there will be changes in various institutions such as the participation of the academic community in terms of innovation and the activity of online learning with the themes of strategic and solution themes. Especially how the strategy for implementing business planning continues in the new normal era that is adaptable. Moreover, the evidence with a significant increase in new cases in all regions from the end of July to mid-August 2020, reached 100,000 new claims, followed by about $5 \%$ of the total points and the number of confirmed cases of death nationally. So one effort to reduce the rising wave of national concern is academics' participation in studying economic

Arief, A. S., Mulyadi, M., \& Liriwati, F. Y. (2021). The sustainable business strategy during the new normal era: lesson for Indonesian academic. International Research Journal of Management, IT and Social Sciences, 8(3), 274285. https://doi.org/10.21744/irjmis.v8n3.1667 
issues and continuing business practices in the new normal era. So based on that reason, this research was conducted with efforts to raise various financial problems, especially sustainable business strategies, and adapt to the state of the country that is still under Covid-19's attention entering a new normal era.

Based on academic efforts to solve the economic crisis's complexity, academics can provide solutions to fill the era of normal adaptation by academic means. Bastow et al. (2014) study may become a collective backrest that the problems and effects of a social trend have invited academics with their study studies to make a difference. Besides how Currie et al. (2020), Queiroz et al. (2020) simulated modeling has helped reduce the difficulty resulting from the Covid-19 pandemic impact in the U.S. lately. With the two examples of the study above will provide a strong impetus for this study to be carried out with the aim in this new normal period this study will look for breakthroughs in economic recovery efforts such as business people and support decision making on strategic government policies through the application of new adaptation learning online at the level university and school. One of the education sector's efforts is to support new normalcy and attention to the national policy by teaching and transferring business strategy content to the university environment. Efforts to apply this approach in the business era of normalization are adapted in the implied curriculum, especially business economics programs at the faculty level end soon. Gates (2020) suggested many roles to the state during the pandemic to try any solution that will be less difficult in the future.

\section{Literature review}

This study will review the sustainability of strategic business learning in the new normal era during the Covid-19. This study will review several related information to support the topic discussion. As mentioned earlier, the pandemic's bad side was not only on human health but also on all human life sectors. However, in this paper, the writer will discuss the sustainability of strategic business that will be learning inputs as right now, most universities are learning to conduct long distances to respond to the government's physical distancing policy. Talking about a sustainable business strategy means talking about a combination of business goals and the social environment that has integrated into the business goals, operations, management, and business planning that has determined towards long-term business sustainability that has highly valued for the business, employees, customers and surrounding communities (Evans et al., 2017; Geissdoerfer et al., 2018; Pieroni et al., 2019; Fernando et al., 2019).

They also suggested that a sustainable business strategy could also have innovated to become a business model and create a sustainable perspective. Similar advice also came from Shen et al. (2010) who see this business sustainability strategy as the key to business success for a moment and its sustainability and the corporate social environment. It is an important effort to create strong business management and implementation with an easy-to-use approach. Other interests of the sustainability of this business strategy are carried out based on enormous benefits not only for the company, social environment, and business continuity going forward but the benefits in policy making and decision making so that the company does not only lead to large profitable businesses but can invite as many investors as possible for future profits.

Learning sustainable business is an important course in the current business application and academic activities, especially entrepreneurial business programs. This course is considered important because of business knowledge and skills, business practices, and insight into its environment, specifically the benefits and future of a sustainable business. For this reason, understanding economic scientists such as Alberti \& Varon Garrido, (2017), Suseno et al. (2018), Raišienė \& Urmanavičiene (2017), who question how business teaching strategies can be achieved together with ongoing teaching efforts, both of which are often at odds with business education objectives, are important to study. Indeed there are no definitive answers that can or cannot. However, Thelken \& de Jong (2020) suggest that the most fundamental business goals are profit and business orientation in a sustainable future, and these two goals have integrated into the academic environment. So with this sustainable business learning model, the purpose of this study can be achieved by prioritizing future orientation with consideration of business competition that is very trusted and reliable that might have achieved.

As earlier noted, the Coronavirus 2019 has left a profound impact and difficulty on the economy and business activities. Then a question arose to whether the government and its citizens could continue their business. This kind of impact resulted from the government's government's Covid-19 needs action and business players' role in a new normal era's synergistic involvement. One way to discuss this problem is to communicate it to an academic audience. Lawson (2009), long before Covid-19 hit the economy, has said about the world economic situation that continues to improve multiple distresses in support of academic contribution with theory and method informing the policymakers is really in need. 
Discussing the impact of Covid-19, Qian et al. (2020) urged that collective work in collaborative academic collaborative action can involve the academic in combating a pandemic as an enemy between nations together. Academics with the study of practical knowledge and application theory know how to build collective community awareness to share a better future for all human beings online globally because Covid-19, as an infectious virus, is no longer an epidemic solution. Thus, a more autonomous and intellectual solution is needed to achieve proven solutions that can be made possible. For this reason, countries, along with related institutions and the wider community, scientists, and academics with integrity, must work hard to find solutions to the effects of a pandemic, especially economic acceleration with a sustainable strategy. One of these efforts is that academic activities reviewing business strategies sustainable in normal times will provide good insights that academics' contributions with peaceful solutions and leadership ideas on core issues will respond to and be recommended to the government. Likewise, health ideas and strategies for economic impact and consumer protection can implement in all practices.

Berwick (2020) provided many options for the new normal era's economic improvement approaches with adaptation. Besides, to understand Indonesian citizens' responses to the uncertainty of the risk of Covid-19 for human health, the community's response was varied. Some are very cautious, and some are not afraid at all. It is an opportunity for the intellectual community to propose self-involvement so that it hopes to improve the two responses to economic recovery through the implementation and understanding of sustainable business so that it has convinced the importance of continuing business in the new normal era. All sectors of human life today, especially the economy, are severely affected by the impact of Covid-19. Although many speculate that Indonesia is now in the category of entering a new normal era, various studies have proven that there is still a long way to go. For example, Donthu \& Gustafsson (2020) survey evaluated the effects of the 2019 coronavirus from a strategic business perspective into research and has stated that progress towards economic improvement is still tough. When entering the new normal era, the study of economic activity strategies and practices usually involves universities. This involvement is very strategic because the university is a place where more resources can answer the wider community's challenges. For this reason, our research studies various contents related to adaptively entering a new normal era. This study is a framework for a business strategy in a period where citizens must be able to coexist with the Coronavirus from a scientist's point of view.

The study with domestic outputs will carry out business leaders' performance running well even though they did not increase significantly after their business activities have disrupted due to Covid-19. Indeed, long before the outbreak plagues the business world, Seo (2015) has argued that business with e-strategy services to fellow businesses in the East and the West has occurred. He said the world was entering a new era of innovation where business activities and strategies have carried out in a modern way or business lines after a new normal period. So, with the presence of the coronavirus disruption that has spread throughout the world, it is no wonder that business strategy studies must find new ways to adapt to the times. For example, what was reviewed by Teece (2010) states that business practices are increasingly developing in various models, but the emphasis on the importance of strategy needs to be improved. He said the businesses that survive are those with sustainable strategies and innovation. Once again, sustainability in business strategy is a necessity and can adjust to the core objective of academic activities, which is to study and distribute the results to the business world and practitioners and public policymakers.

\section{Materials and Methods}

This research reviewed the sustainability of the business strategy learning in the new normal era during the Covid-19 pandemic. This pandemic-related study was conducted by reviewing various recent related issues and literature progress on the above topic according to the direction of a qualitative scientific review method (Creswell, 2009; McNulty et al., 2013; Van Kleef \& Roome, 2007). The paper will summarize the current data on this topic that carried out systematically by following the Research Skills Development (RSD) framework application, a conceptual research application to enrich the university research community-initiated and developed by Willison \& O'Regan (2007) and support by a review of the perceptions and online learning in higher education research. (Abdurrahman et al., 2017). The earliest facet as presented in terms of Research Skill Development framework is 'Embark,' determining the theme of the study specifically, then proceeding with the 'to find' aspect of information, efforts to apply search engines to search for information related to the study theme online and systematically, for example with the keywords "business strategy" and "new normal era." The next step is to 'evaluate' the information to ensure that the data matches the review's purpose, then aspects " organize and analyze. "Finally, facet 'application' to attract cases, the impulse follows the 'communication.' These facets, ensuring the information and data analyzed within the RSD framework, have answered questions of a research problem so that the process of finding the results of this study meets the principles

Arief, A. S., Mulyadi, M., \& Liriwati, F. Y. (2021). The sustainable business strategy during the new normal era: lesson for Indonesian academic. International Research Journal of Management, IT and Social Sciences, 8(3), 274- 
of validity and reliability. Sources for reviewing data and information include publication papers, newspapers, websites, and others.

\section{Results and Discussions}

\section{Business Continuity Strategy}

The discussion of various kinds of literature on business strategy that continues in the new normal era is an important topic for various prospects for business continuity. One of them is the strategy for continuing the tourism and hospitality business, which is still quiet until entering a new normal era after Covid-19. The experience of several countries that previously faced the new normal era highlighted the tourism business's specific content after their countries experienced a high increase in the development of the tourism industry so that GDP in some countries experienced an increase of almost $10 \%$. So since the COVID outbreak, they are now entering a new normal era with a new sustainable development strategy.

\section{B2B strategy}

Even though the signs of the Covid-19 outbreak have subsided, several big questions marks still haunt the economic future of an affected country. This is an impact marked by difficulty in livelihoods and high unemployment. Even so, business players remain optimistic about various trading strategies. One of them is the business-to-business (B2B) strategy, the era of business practices facing various crises entering a new normal era. This strategy is indeed impossible to implement in an era of free and tight competition. However, based on common thoughts about the Covid-19 response, business people are willing to match their hands with B2B strategies in the new normal era.

\section{Opportunity Strategy}

The impact of the 2019 coronavirus pandemic is the toughest challenge after World War. Most affected countries have stated that they are ready to welcome the new normal era to the normal old era. Many reports that the positive impact of the Covid-19 outbreak is on increasing social cooperation and responsibility among business people both on business strategy and philosophy. Several lessons can take from this pandemic. It is a new opportunity for new business strategies. A pandemic will be becoming a collective warning that the business world must have new systems and strategies towards sustainability and social and environmental justice.

\section{Rethink Strategy}

Rethinking strategy is a sustainable strategy that is very appropriate for a new approach to continue business in the new normal era. Running a business in uncertain times requires a distinctive strategy so that people can prepare businesses for all kinds of difficulties caused by a pandemic. This pandemic is a tough challenge between rethinking and redesigning new business strategies with a sustainable and adaptable approach in an era where the impact of Covid19 still haunts the world. Business actors' agility and resilience in integrating these strategies into sustainable business practices in the new normal era are considered a challenge in itself. These are valuable lessons to arouse the collective thinking of businesspeople in countries affected by the pandemic.

\section{Lesson Learned Strategy}

The learning strategy is a business mindset by taking lessons from the Covid-19 pandemic emergence, which sometimes escapes from a business perspective. This strategy is important when many business people tend only to see the presence of Covid-19 on the negative side. Because the readiness of business people to enter the new normal era requires strategic adjustments and adaptations between thinking about a profitable business and accepting this is natural change and settings. 


\section{The Work from Home Strategy}

The new working method from home is not new in some developed countries where technical support and company policies are already very possible. However, since the impact of Covid-19 hit the world, companies and governments have started to make the employees work from home as a temporary solution. This trend considers being one of the good strategic policies for employees so that business continues by adopting healthy ways of working in a collective effort to break the chain of the spread of the Coronavirus in countries exposed to a very serious pandemic.

\section{Effected policy}

The implementation of effective policies in each company is part of business people's efforts to avoid the impact of Covid-19 on various current and future business activities. Along with the emergence of an outbreak with an impact on business, business people must have the right policies and strategies so that they can lead businesses on a sustainable path into a new normal era. Related studies prove that business executives and policymakers must be able to read ahead with all policies and strategies so that their businesses will continue to prepare for all trials. So employers and policymakers must have selected sustainable strategies for businesses, consumers, employees, and the surrounding social environment.

\section{New Mindset Strategy}

The new mindset strategy must be one of the priorities for business people in difficult times due to Covid-19. This preoccupation and glorious time is a mindset that does not need during the economy and business downturn. Over time with the Coronavirus's impact, the mindset of business people must change to be able to adapt to new conditions entering normal conditions and after the Covid-19 outbreak. By fixing the right mindset, there is an opportunity to change how businesses run to remain sustainable. For this reason, business leaders must continue to realize that there are many new strategies, including a new mindset strategy, always to be able to return their business to continue to survive even though the new normal era still haunts the shadow of the coronavirus and world economic difficulties.

\section{Strategic flexibility}

Strategic flexibility is a business strategy that emphasizes a flexible approach that every business person was suffering from COVID-19 must-have. Many business experts say that the business world is currently in a period of greatest challenges after World War II. Get out of this difficulty, and a business must have a high flexibility strategy to innovate the business so that it can enter a new normal. Nicola et al. (2020) note that this pandemic has strong socio-economic impacts and implications for businesses in seriously affected countries. The right solution is the spirit of business leaders' flexibility with all kinds of strategies from technology adoption and strengthening human resources to adapt to challenges easily. Regarding flexibility in business practices, many have suggested that business people must link marketing and employee human resources by using technology support to reach customers who are also affected by the pandemic.

\section{Understanding New Business Strategy}

The ultimate search strategy is understanding new business strategies. Understanding business strategy in the Covid19 era is very important for every business leader because they dream of their business to thrive and sustain to the peak of success, especially when their business returns to normal days long after Covid-19 left. The understanding and skills of every business person must improve the quality of their business strategy appropriately and accurately. The study of various business strategy understandings shows that there are at least three basic strategic references if a business wants to gain an advantage and competition. For example, understanding business strategy focuses on objectives, availability of sufficient venture capital, and specialization in a particular business to understand the business operates in a less competitive area.

Arief, A. S., Mulyadi, M., \& Liriwati, F. Y. (2021). The sustainable business strategy during the new normal era: lesson for Indonesian academic. International Research Journal of Management, IT and Social Sciences, 8(3), 274285. https://doi.org/10.21744/irjmis.v8n3.1667 


\section{Discussion}

The study objective is to discuss some of the sustainability of business strategies that are good for running a business in the new normal era during the Covid-19 pandemic. The results of this study are to add insight into new application materials for academics in Indonesia, especially students in business and entrepreneurship programs. The first point is the continuity of a business strategy that is the better one to run a business in the new normal era. Gyimóthy et al., (2020) illustrate that the presence of the Covid-19 pandemic crisis creates an important opportunity for many parties, such as academician innovation, with the government policy to get out of the unsustainable inter-country tourism business when each country issued a travel and movement restriction policy. So in the new normal era, economy and business activities shall be restart and reopening with a new strategy.

A second search of this study reviewed business to business strategy (B2B). A study was done by Crick \& Crick (2020), which examined the importance of businesspeople working together in difficult times due to the impact of the COVID-19 becoming a common understanding among businesses. They showed this B2B strategy operated and medical industries looking for drugs and vaccines to fight coronavirus 2019 as common enemies both in the new normal and after. The next finding was an opportunity as a new business strategy that is good to apply during the pandemic time. Fernandes (2020) reports that more and more countries show their economies are seriously affected by the coronavirus outbreak through disruption of industrial activities to economic crises in several countries affected by COVID. Coronavirus's impact does bring not only human health problems but also burdens political, sociologycultural, business, economics, worship, and human survival around the world. Realizing these impacts, all business leaders have worked together to solve common problems. A similar study was also from Wenham et al. (2020), which also reported that Covid-19 also impacts gender. With the Covid-19 incident, the world, especially the women and children who suffered the most, must be able to accept it as a recession with multiple impacts in the history of civilization to use this as an opportunity to unity and working with the same action and understanding (Buheji \& Ahmed, 2020).

The rethinking strategy was also a potential business strategy was applied in most business operation. After the Covid19 entered global concern, more countries and business leaders to rethink and reshape their business strategy. A study by Donthu \& Gustafsson (2020) noted that the impact of COVID-19 on businesses was so diverse, and it must be a way to develop the latest studies to reshape the business through strengthening studies and development. A similar idea was from Vancic \& Pärson (2020) that stressed the changes in buyer behavior during the COVID-19 period had affected sales, especially the issue of price and service quality where consumers' condition is not very stable. So efforts to improve business skills after the pandemic must be different from before Covid-19. Another reason is to prioritize understanding and fulfilling changes in consumer behavior as well as the needs of employees to have new skills such as the ability to serve consumers digitally, social interactions, and the demands of other competitive service tasks that also color the way businesses interact by changing rethinking and re-skill in business running.

The Covid-19 and its impacts on human life and activities, including business, shall not be seen as difficult, but as a lesson learned. At least what Craven et al. (2020) review, the impact of business strategy changes due to Covid-19, where small and large scale business people felt the various impacts with its implications. Among the trendiest changes, such as the adoption of digital technology, which was increasingly grounded both before the outbreak and entering a new normal era. This trendy has made business people realize that people can not see digital technology as a luxurious thing usually used by limited circles. Since the new normal era, the trend of adopting digital machines in business has become an absolute necessity as part of a healthy competitive strategy, benefiting all parties in the business and consumer circles. Seetharaman (2020) also reviewed changes and shifts in a business strategy where he examined various business models' changes as a positive impact of the emergence of Covid-19.

Everyone agrees that the citizen strategy to continue working from home is the most suitable solution applied in the new normal era in all affected countries (Arizona State University et al., 2020). They added that work from home after the Covid-19 outbreak as a better solution. They have recorded that approximately $35.2 \%$ of U.S. citizens since Covid-19 have worked at home. This trend shows that working from home is a strategic effort agreed upon by both workers and the company. The reason for keeping working at home is also closely related to the effect of losing the job, especially during the difficulties of the pandemic. They also observed that more than 75 percent of employees worked from home voluntarily until the end of the limited term.

Choosing an effective strategy is very crucial in sustaining the business during the Covid-19. To find strategies and policies that relevant to economic policies entering a new normal era, economists, business people, sustainable business policy specialists, and other experts have contributed their input to support businesses that can sustain from the impact of Covid-19, which is this outbreak has no sign of ending. The other policy suggested by Carroll \& Conboy (2020) is 
very appropriate to anticipate this situation. They normalize the new normal era by adopting the latest policy on fresh funds into small business capital in a time of increasingly international pandemic pressure in business management, especially in handling the information tasks.

One approach to small business sustainability is the policy of allocating fresh funds aimed at supporting small communities by the government and supporting business actors such as traders by not increasing the price of basic household goods. The government must have a policy that assists indirect incentives in the form of BLT in Indonesia to the most affected communities. People have seen this example method, Bird \& Hernández (2012), who examined alternative policies to provide direct incentives to small traders and the population most affected by entering a new normal era.

Since the Covid-19 impacted the economy, more business people can not move on even in the new normal. It is because they are unable to change their mindset over the current situation affect them. So, to pass this difficult time, all business players shall have a new mindset. Some are leaders who were enjoying great economic growth before the Covid-19. Adjusting a business mindset into the new normal era's right conditions is not easy, and that is why business leaders need to learn to set their business mindset properly. Chan et al. (2018) argued that business leaders need a certain conceptual framework to apply to carry out a global business-oriented business mindset and global business change. The expertise of business leaders will set the mindset path of a challenging and safe zone like the business strategy before the Covid-19 outbreak is critical.

Flexibility in running a business starts with the ability of a leader in business management, then with the support of using an online presence, it allows the leader to achieve success without limits. According to a study conducted by Ahmad \& Murad (2020), such flexibility is part of the positive influence of social media on the business world when there is a very positive lockdown panic in several countries in the Middle East. So fitting that this strategy needs application in Indonesia, not only for large entrepreneurs but even small businesses must gradually adopt technology to increase business growth in the new normal era so that businesses can be more sustainable in the future.

Regarding business understanding strategies, Agyapong \& Boamah (2013) argue that selecting the right business strategy starts with understanding the correct business strategy. Here, understanding the correct strategy will make the business appear superior in addition to having sufficient capital to support both startups and sustainable business operations. A good understanding of business strategy will enable the business to be more efficient in ensuring business operations continuity. Lohri et al. (2014) explain that a company's financial sustainability is very dependent on capital ownership and understanding how to choose the right strategy so that it can reduce outgoing costs in supporting its business operations to be sustainable.

\section{Conclusion}

This study has successfully reviewed several sustainable business strategies during the new post-COVID-19 normal era: important Indonesian academics lessons. Through the above topic, this study wants to explore some business strategies that are adaptable to Indonesia's economic situation, which is currently still overshadowed by the difficulties caused by the Covid-19 impact crisis. Then the results of this review can be contributed by academics in Indonesia, especially students in economics and business programs. It hopes that with this input, the parties can benefit both academics and business people who are now entering a new normal era filled with business uncertainty. As for the summary of this study, we can conclude that when the national economy and business atmosphere is in trouble due to the impact of Covid-19, then one way for their business to continue to survive and have high sustainability is by strengthening practical strategic input allowing it easy for them to understand and apply them in the business field. The ten adaptable business strategies that have discussed include; sustainability and sustainability business, business to business or B2B strategy, opportunity strategy, rethinking and redesigning strategy, lesson learned strategy, working from home strategy, affected and selected policy, new mindset strategy, flexibility strategy, and understanding strategy of new strategies. So with this new sustainable business strategic finding, it is hoped that academics, especially students majoring in business and entrepreneurs and business people in the new normal era, can take advantage to improve understanding of business strategies in running all their businesses to achieve their good business status

Conflict of interest statement

The author(s) declared that they have no competing interests.

Arief, A. S., Mulyadi, M., \& Liriwati, F. Y. (2021). The sustainable business strategy during the new normal era: lesson for Indonesian academic. International Research Journal of Management, IT and Social Sciences, 8(3), 274285. https://doi.org/10.21744/irjmis.v8n3.1667 
Statement of authorship

The author(s) have a responsibility for the conception and design of the study. The author(s) have approved the final article.

\section{Acknowledgments}

We want to express our deepest gratitude for all the support of colleagues and supervisors in academia both from the beginning and at the time of reporting this paper. The same goes for the funding parties without whom we could not have done more. We admit that this project has not been as expected, but it has reached our target as beginners in academia. Our project with the theme "The Sustainable Business Strategy During The New Normal Era: Lesson For Indonesian Academic" Hope it is worthwhile. 


\section{References}

Abdurrahman, D., Willison, J., \& Sabir, F. (2017). International postgraduate students' perception of the research skill development framework. National Conference on Teachers' Professional Conference, 1(0), 77-81.

Agyapong, A., \& Boamah, R. B. (2013). Business Strategies And Competitive Advantage Of Family Hotel Businesses In Ghana: The Role Of Strategic Leadership. Journal of Applied Business Research (JABR), 29(2), 531-544. https://doi.org/10.19030/jabr.v29i2.7654

Ahmad, A. R., \& Murad, H. R. (2020). The Impact of Social Media on Panic During the COVID-19 Pandemic in Iraqi Kurdistan: Online Questionnaire Study. Journal of Medical Internet Research, 22(5), e19556. https://doi.org/10.2196/19556

Alberti, F. G., \& Varon Garrido, M. A. (2017). Can profit and sustainability goals co-exist? New business models for hybrid firms. Journal of Business Strategy, 38(1), 3-13. https://doi.org/10.1108/JBS-12-2015-0124

Arizona State University, Bick, A., Blandin, A., Virginia Commonwealth University, Mertens, K., \& Federal Reserve Bank of Dallas. (2020). Work from Home After the COVID-19 Outbreak. Federal Reserve Bank of Dallas, Working Papers, 2020(2017). https://doi.org/10.24149/wp2017

Bastow, S., Dunleavy, P., \& Tinkler, J. (2014). The Impact of the Social Sciences: How Academics and their Research Make a Difference (1 edition). SAGE Publications Ltd.

Berwick, D. M. (2020). Choices for the "New Normal". JAMA, 323(21), 2125-2126. https://doi.org/10.1001/jama.2020.6949

Bird, S., \& Hernández, D. (2012). Policy options for the split incentive: Increasing energy efficiency for low-income renters. Energy Policy, 48, 506-514. https://doi.org/10.1016/j.enpol.2012.05.053

Buheji, M., \& Ahmed, D. (2020). Foresight of Coronavirus (COVID-19) Opportunities for a Better World. American Journal of Economics, 10(2), 97-108.

Bocken, N. M., Short, S. W., Rana, P., \& Evans, S. (2014). A literature and practice review to develop sustainable business model archetypes. Journal of cleaner production, 65, 42-56. https://doi.org/10.1016/j.jclepro.2013.11.039

Caldera, H. T. S., Desha, C., \& Dawes, L. (2019). Evaluating the enablers and barriers for successful implementation of sustainable business practice in 'lean'SMEs. Journal of Cleaner Production, 218, 575-590. https://doi.org/10.1016/j.jclepro.2019.01.239

Cai, W., McKenna, B., Wassler, P., \& Williams, N. (2020). Rethinking knowledge creation in Information Technology and Tourism. Journal of Travel Research, 0047287520946100.

Caraka, R. E., Lee, Y., Kurniawan, R., Herliansyah, R., Kaban, P. A., Nasution, B. I., Gio, P. U., Chen, R. C., Toharudin, T., \& Pardamean, B. (2020). Impact of COVID-19 large scale restriction on environment and economy in Indonesia. Global Journal of Environmental Science and Management, 6(Special Issue (Covid-19)), 65-84. https://doi.org/10.22034/GJESM.2019.06.SI.07

Carroll, N., \& Conboy, K. (2020). Normalising the "new normal": Changing tech-driven work practices under pandemic time pressure. International Journal of Information Management, 102186. https://doi.org/10.1016/j.ijinfomgt.2020.102186

Chan, K. C., Fung, A., Fung, H.-G., \& Yau, J. (2018). A Conceptual Framework for Instilling a Global Mindset in Business Students. Journal of Teaching in International Business, 29(1), 4-19. https://doi.org/10.1080/08975930.2018.1455907

Cohen, J. H. (2020). Modeling Migration, Insecurity and COVID-19. Migration Letters, 17(3), 405-409.

Craven, M., Liu, L., Mysore, M., \& Wilson, M. (2020). COVID-19: Implications for business. McKinsey \& Company.

Creswell, J. W. (2009). Research Design: Qualitative, Quantitative, and Mixed Methods Approaches (3rd ed.). SAGE.

Crick, J. M., \& Crick, D. (2020). Coopetition and COVID-19: Collaborative business-to-business marketing strategies in a pandemic crisis. Industrial Marketing Management, 88, 206-213. https://doi.org/10.1016/j.indmarman.2020.05.016

Currie, C. S. M., Fowler, J. W., Kotiadis, K., Monks, T., Onggo, B. S., Robertson, D. A., \& Tako, A. A. (2020). How simulation modelling can help reduce the impact of COVID-19. Journal of Simulation, 14(2), 83-97. https://doi.org/10.1080/17477778.2020.1751570

Donthu, N., \& Gustafsson, A. (2020). Effects of COVID-19 on business and research. Journal of Business Research, 117, 284-289. https://doi.org/10.1016/j.jbusres.2020.06.008

Evans, S., Vladimirova, D., Holgado, M., Fossen, K. V., Yang, M., Silva, E. A., \& Barlow, C. Y. (2017). Business Model Innovation for Sustainability: Towards a Unified Perspective for Creation of Sustainable Business Models. Business Strategy and the Environment, 26(5), 597-608. https://doi.org/10.1002/bse.1939

Arief, A. S., Mulyadi, M., \& Liriwati, F. Y. (2021). The sustainable business strategy during the new normal era: lesson for Indonesian academic. International Research Journal of Management, IT and Social Sciences, 8(3), 274- 
Fernandes, N. (2020). Economic effects of coronavirus outbreak (COVID-19) on the world economy. Available at SSRN 3557504.

Fernando, Y., Jabbour, C. J. C., \& Wah, W. X. (2019). Pursuing green growth in technology firms through the connections between environmental innovation and sustainable business performance: does service capability matter?. Resources, Conservation and Recycling, 141, 8-20. https://doi.org/10.1016/j.resconrec.2018.09.031

Gates, B. (2020). Responding to Covid-19-A Once-in-a-Century Pandemic? New England Journal of Medicine, 382(18), 1677-1679. https://doi.org/10.1056/NEJMp2003762

Geissdoerfer, M., Vladimirova, D., \& Evans, S. (2018). Sustainable business model innovation: A review. Journal of cleaner production, 198, 401-416. https://doi.org/10.1016/j.jclepro.2018.06.240

Gyimóthy, S., Pérez, S. M., Meged, J. W., \& Wilson, J. (2020). Editorial: Contested spaces in the sharing economy. Scandinavian Journal of Hospitality and Tourism, 20(3), $205-211$. https://doi.org/10.1080/15022250.2020.1789502

Hofacker, C. (2020). SMEs in B2B Markets in Times of Crisis. American Marketing Association. https://www.ama.org/listings/2020/07/16/smes-in-b2b-markets-in-times-of-crisis/

Joyce, A., \& Paquin, R. L. (2016). The triple layered business model canvas: A tool to design more sustainable business models. Journal of cleaner production, 135, 1474-1486. https://doi.org/10.1016/j.jclepro.2016.06.067

Lawson, T. (2009). The current economic crisis: Its nature and the course of academic economics. Cambridge Journal of Economics, 33(4), 759-777. https://doi.org/10.1093/cje/bep035

Lohri, C. R., Camenzind, E. J., \& Zurbrügg, C. (2014). Financial sustainability in municipal solid waste management - Costs and revenues in Bahir Dar, Ethiopia. Waste Management, 34(2), 542-552. https://doi.org/10.1016/j.wasman.2013.10.014

McNulty, T., Zattoni, A., \& Douglas, T. (2013). Developing Corporate Governance Research through Qualitative Methods: A Review of Previous Studies. Corporate Governance: An International Review, 21(2), 183-198. https://doi.org/10.1111/corg.12006

Naumov, N., Varadzhakova, D., \& Naydenov, A. (2020). Sanitation and hygiene as factors for choosing a place to stay: Perceptions of the Bulgarian tourists. Anatolia, 1-4.

Nicola, M., Alsafi, Z., Sohrabi, C., Kerwan, A., Al-Jabir, A., Iosifidis, C., Agha, M., \& Agha, R. (2020). The socioeconomic implications of the coronavirus pandemic (COVID-19): A review. International Journal of Surgery (London, England), 78, 185-193. https://doi.org/10.1016/j.ijsu.2020.04.018

Novitasari, D. C. R., Hendradi, R., Caraka, R. E., Rachmawati, Y., Fanani, N. Z., Syarifudin, A., Toharudin, T., \& Chen, R. C. (2020). Detection of COVID-19 chest X-ray using support vector machine and convolutional neural network. Commun. Math. Biol. Neurosci., 2020, Article-ID.

Pieroni, M. P., McAloone, T. C., \& Pigosso, D. C. (2019). Business model innovation for circular economy and sustainability: A review of approaches. Journal of Cleaner Production, 215, 198-216.

Prideaux, B., Timothy, D., \& Cooper, M. (2009). Introducing river tourism: Physical, ecological and human aspects. River Tourism, 1-21.

Qian, X., Ren, R., Wang, Y., Guo, Y., Fang, J., Wu, Z.-D., Liu, P.-L., Han, T.-R., Mao, Z.-F., Jiang, Y., Wang, T.-P., Zhang, J.-H., Zhang, Q.-M., Zhang, Z.-Y., Zhou, H.-N., Chen, F., \& Members of Steering Committee, S. of G. H., Chinese Preventive Medicine Association. (2020). Fighting against the common enemy of COVID-19: A practice of building a community with a shared future for mankind. Infectious Diseases of Poverty, 9(1), 34. https://doi.org/10.1186/s40249-020-00650-1

Queiroz, M. M., Ivanov, D., Dolgui, A., \& Wamba, S. F. (2020). Impacts of epidemic outbreaks on supply chains: Mapping a research agenda amid the COVID-19 pandemic through a structured literature review. Annals of Operations Research, 1-38.

Raišienè, A. G., \& Urmanavičienè, A. (2017). Mission drift in a hybrid organization: How can social business combine its dual goals? Ekonomski Vjesnik, 30(2), 301-310.

Seetharaman, P. (2020). Business models shifts: Impact of Covid-19. International Journal of Information Management, 54, 102173. https://doi.org/10.1016/j.ijinfomgt.2020.102173

Seo, D.-S. (2015). E-Strategy between European and Korean Innovative Business Channels in Post-New Normal Era. The Journal of Business, Economics, and Environmental Studies (JBEES), 5(4), 59-66.

Shen, L., Tam, V. W. Y., Tam, L., \& Ji, Y. (2010). Project feasibility study: The key to successful implementation of sustainable and socially responsible construction management practice. Journal of Cleaner Production, 18(3), 254259. https://doi.org/10.1016/j.jclepro.2009.10.014 
Sigler, T., Mahmuda, S., Kimpton, A., Loginova, J., Wohland-Jakhar, P., Charles-Edwards, E., \& Corcoran, J. (2020). The Socio-Spatial Determinants of COVID-19 Diffusion: The Impact of Globalisation, Settlement Characteristics and Population.

Sirkeci, I., \& Yucesahin, M. M. (2020). Coronavirus and Migration: Analysis of Human Mobility and the Spread of Covid-19. Migration Letters, 17(2), 379-398. https://doi.org/10.33182/ml.v17i2.935

Sun, Q., Zhou, W., Kabiri, A., Darzi, A., Hu, S., Younes, H., \& Zhang, L. (2020). COVID-19 and Income Profile: How People in Different Income Groups Responded to Disease Outbreak, Case Study of the United States. ArXiv Preprint ArXiv:2007.02160.

Suseno, Y., Laurell, C., \& Sick, N. (2018). Assessing value creation in digital innovation ecosystems: A Social Media Analytics approach. The Journal of Strategic Information Systems, 27(4), 335-349.

Teece, D. J. (2010). Business Models, Business Strategy and Innovation. Long Range Planning, 43(2), $172-194$. https://doi.org/10.1016/j.lrp.2009.07.003

Thelken, H. N., \& de Jong, G. (2020). The impact of values and future orientation on intention formation within sustainable entrepreneurship. Journal of Cleaner Production, 266, 122052. https://doi.org/10.1016/j.jclepro.2020.122052

Toharudin, T., Caraka, R. E., Chen, R. C., \& Nugroho, N. T. (2020). Bayesian Poisson Model for COVID-19 in West Java Indonesia. Sylwan, 164(6), 279-290.

Van Kleef, J. A., \& Roome, N. J. (2007). Developing capabilities and competence for sustainable business management as innovation: a research agenda. Journal of cleaner production, 15(1), 38-51. https://doi.org/10.1016/j.jclepro.2005.06.002

Vancic, A., \& Pärson, G. F. A. (2020). Changed Buying Behavior in the COVID-19 pandemic: The influence of Price Sensitivity and Perceived Quality. http://urn.kb.se/resolve?urn=urn:nbn:se:hkr:diva-20904

Wenham, C., Smith, J., \& Morgan, R. (2020). COVID-19: The gendered impacts of the outbreak. The Lancet, 395(10227), 846-848. https://doi.org/10.1016/S0140-6736(20)30526-2

Willison, J., \& O’Regan, K. (2007). Commonly known, commonly not known, totally unknown: A framework for students becoming researchers. Higher Education Research \& Development, 26(4), 393-409. https://doi.org/10.1080/07294360701658609

Arief, A. S., Mulyadi, M., \& Liriwati, F. Y. (2021). The sustainable business strategy during the new normal era: lesson for Indonesian academic. International Research Journal of Management, IT and Social Sciences, 8(3), 274285. https://doi.org/10.21744/irjmis.v8n3.1667 